\title{
Perilaku Asosiatif Siswa Sekolah Dasar Melalui Pendekatan Bermain Dalam Konteks Pembelajaran PJKO
}

\author{
Aschari Senjahari Rawe \\ e-mail: ascharisenjaharirawe@gmail.com
}

Program Studi Pendidikan Guru Sekolah Dasar, FKIP, Universitas Flores

\begin{abstract}
ABSTRAK: Kompetensi social merupakan kemampuan guru berhubungan dengan lingkungan masyarakat sekolah dan luar sekolah, guru mampu bergaul,berkomunikasi,melayani masyarakat dengan baik, menunjang kreativitas masyarakat,serta menjaga emosi dan perilaku yang kurang baik yang ada di lingkungan masyarakat. Dengan perilaku yang dapat ditiru, sosok guru menjadi parameter perilaku masyarakatnya.kompetensi social inilah yang harus menjadi cirri guru dalam memposisikan dirinya dengan masyarakat,setiap gerak dan langkah guru selalu mendapat perhatian.perubahan hubungan sosial melalui kegiatan pendidikan jasmani adalah terciptanya rasa persatuan yang erat diantara pelaku proses pembelajaran serta hubungan guru dan murid akan menjadi lebih baik. Ini terjadi apabila guru mampu menyajikan bahan ajar yang sesuai dengan tingkat perkembangan siswa, guru menjadi tauladan bagi setiap siswa.
\end{abstract}

Kata kunci: pendekatan pembelajaran bermain pjko, perilaku asosiatif.

ABSTRACT: Social competence is the ability of teachers to relate to the environment of the school community and outside school, teachers are able to get along, communicate, serve the community well, support the creativity of the community, and maintain the emotions and behavior that is not good in the community. With behaviors that can be imitated, the figure of the teacher becomes a parameter of the behavior of the community. This social competence must be the hallmark of the teacher in positioning himself with the community, every move and step of the teacher always gets attention. The change in social relations through physical education activities is the creation of a close sense of unity between learning process actors and the relationship between teacher and student will be better. This happens if the teacher is able to present teaching materials that are appropriate to the level of student development, the teacher becomes an example for each student.

Keywords: associative behavior, learning approach to play PJKO 


\section{PENDAHULUAN}

Kehidupan sekolah yang demikian berkombinasi pula dengan kehidupan dirumah dan lingkungan luar sekolah. Jika sekolah anak kurang bergerak, di rumah keadaannya juga demikian. Kemajuan teknologi yang dicapai pada saat ini, malah mengungkung anak - anak dalam lingkungan kurang gerak. Anak semakin asyik asyik dengan kesenangan seperti menonton TV atau bermain video game.tidak mengherankan bila ada kerisauan bahwa kebugaran anak - anak semakin menurun dengan demikian rendahnya kebugaran jasmani, kian meningkat pula gejala penyakit hipokinetik (kurang gerak).beban belajar di sekolah begitu berat dan menekan kebebasan anak untuk bergerak,kebutuhan mereka akan gerak tidak bisa terpenuhi karena keterbatasan waktu dan kesempatan. Lingkungan sekolah tidak menyediakan wilayah yang menarik untuk dijelajahi Husdarta H.J.S. (2011). Penyelenggara pendidikan di sekolah yang lebih mengutamakan prestasi,akademis, memberikan anak tugas - tugas belajar yang menumpuk. Pendidikan jasmani tampil untuk mengatasi masalah tersebut sehingga kedudukannya dianggap penting. Melalui program yang direncanakan secara baik ,anak dilibatkan dalam kegiatan fisik yang tinggi intensitasnya, pendidikan jasmani juga tetap menyediakan ruang untuk belajar menjelajahi lingkungan yang ada di sekitarnya dengan banyak mencoba, sehingga kegiataanya tetap sesuai dengan minat anak, lewat pendidikan jasmanilah anak - anak menemukan saluran yang tepat untuk bergerak bebas dan meraih kembali keceriaanya, sambil terangsang perkembangan yang bersifat menyeluruh.

Rosdiana, Dini. (2013).Kompetensi social merupakan kemampuan guru berhubungan dengan lingkungan masyarakat sekolah dan luar sekolah, guru mampu bergaul,berkomunikasi,melayani masyarakat dengan baik, menunjang kreativitas masyarakat,serta menjaga emosi dan perilaku yang kurang baik yang ada di lingkungan masyarakat, jadi, guru harus dapat menempatkan diri sesuai dengan tugas dan fungsinya sebagai pendidikan baik untuk siswa disekolah maupun masyarakat yang ada di luar sekolah. Keberadaan guru sangat diharapkan karena dapat memberikan keteladanan bagi lingkungannya. Dengan perilaku yang dapat ditiru, sosok guru menjadi parameter perilaku masyarakatnya.kompetensi social inilah yang harus menjadi cirri guru dalam memposisikan dirinya dengan masyarakat,setiap gerak dan langkah guru selalu mendapat perhatian. Perilaku baik dan buruk seorang guru akan dinilai oleh masyarakat sebagai sebuah norma yang tidak tertulis. Bahkan dalam masyarakat tradisional,kedudukan guru sangat tinggi karena harus menjadi pemberi solusi dalam berbagai persoalan yang ada dalam masyarakat.

\section{PEMBAHASAN}

\section{Pendidikan Jasmani Bagi Kehidupan Sosial Siswa}

Pendidikan jasmani merupakan suatu proses pendidikan yang berhu-bungan dengan upaya-upaya mengembangkan seluruh potensi siswa. Oleh karenahanya pendidikan jasmanilah yang menumbuh kembangkan seluruh aspek siswa seperti aspek kognitif, afektif (sosial dan emosional), dan psikomotor bila dibandingkan dengan mata pelajaran yang lain. Misalnya matematika, fisika, kimia dan mata pelajaran yang bersifat teoritis, maka proses pengembangan aspek yang dimiliki siswa terbatas kepada proses mengembangkan aspek kognitif. Sedangkan dalam pembelajaran penjas potensi utama yang diupayakan untuk semakin berkembang adalah gerak dan perilaku siswa 
secara seimbang, termasuk di dalamnya mengembangkan aspek kognitif. Melalui pelaksanaan program pendidikan jasmani yang teratur, perkembangan hidup siswa akan semakin tumbuh sempurna, bukan hanya pertumbuhan dan perkembangan tubuhnya saja, melainkan juga keadaan emosi, mental, dan hubungan sosialnya menjadi lebih baik karena mampu berinteraksi melalui sikap dan perilaku yang direstui masyarakat Suherman, Adang. (2000). Perubahan tersebut tidak hanya terjadi di lingkungan sekolah tetapi akan terbawa dalam kehidupan siswa di lingkungan masyarakat tempat tinggalnya.Contoh perubahan hubungan sosial melalui kegiatan pendidikan jasmani adalah terciptanya rasa persatuan yang erat diantara pelaku proses pembelajaran serta hubungan guru dan murid akan menjadi lebih baik. Ini terjadi apabila guru mampu menyajikan bahan ajar yang sesuai dengan tingkat perkembangan siswa, guru menjadi tauladan bagi setiap siswa, dan proses pembelajaran berlangsung dengan kondusif. Ketika guru menugaskan siswa membentuk dua kelompok untuk bermain bola tangan maka setiap anggota akan memiliki ikatan yang kuat terhadap kelompoknya (in-group feeling) dibandingkan terhadap kelompok lain. Seperti dikemukakan "Husdarta H.J.S. (2011) Mereka dapat merasakan perlunya hubungan antara mereka yang lebih erat untuk menyesuaikan diri dalam pembentukan kelompok, mempertahankan kesatuan dan persatuan yang lebih baik. Demikian pula hubungan mereka dengan gurunya akan terjalin dengan baik tanpa ada rasa ketakutan." Melalui proses perkembangan perasaan itu, siswa dapat mengubah dirinya, baik secara mental, emosional, maupun intelektualnya untuk membawa perubahan ke arah pembentukan kepribadian yang lebih baik.

Pelaksanaan pendidikan jasmani di lingkungan sekolah selalu diupa-yakan agar siswa merasakan kegembiraan, memperoleh kesenangan, dan mampu memfasilitasi penyaluran keinginan (hobi). Aktivitas pendidikan yang menggem-birakan dan menyenangkan merupakan salah satu upaya mengurangi ketegangan mental siswa yang dialaminya akibat terus menerus duduk di dalam kelas. Dengan mengikuti aktivitas jasmani yang menggembirakan dalam penjas, siswa akan memperoleh kesegaran kembali dan memiliki kesiapan dalam melaksa-nakan aktivitas berikutnya, khususnya dalam interaksi sosial di lingkungan dan suasana yang baru. Pendidikan jasmani hanya akan memiliki arti bagi kehidupan siswa apabila program pendidikan jasmani telah dilaksanakan sesuai dengan arti, maksud, dan tujuan pendidikan jasmani itu sendiri. Faktor lain yang mempengaruhi kebermak-naan pendidikan jasmani adalah kesadaran siswa untuk terlibat secara aktif dalam aktivitas pendidikan jasmani. Di sini peran guru sangat besar dalam memberikan pengaruh terhadap perubahan kesadaran yang semakin tinggi akan arti penting-nya mengikuti program pendidikan jasmani.

\section{Proses asosiatif}

Dalam konteks pendidikan jasmani, interaksi sosial dalam bentuk asosiatif dikemukakan oleh Husdarta H.J.S. (2011).adalah interaksi sosial merupakan proses yang saling memberikan pengaruh di antara anggota kelompok. Dalam konteks pendidikan jasmani, proses saling mempengaruhi berkenaan dengan tugastugas seperti belajar keterampilan, atau melakukan suatu permainan, atau proses sosial antara guru dengan murid, atau dengan kelompok murid. Pada aktivitas pembelajaran ketika guru memberi instruksi, kemudian siswa melaksanakannya, maka interaksi itu mengarah kepada bentuk yang positif sebagai upaya bekerja sama untuk mencapai tujuan bersama dalam 
pembelajaran pendidikan jasmani. Proses asosiatif adalah proses yang menuju kepada suatu kerja sama melalui keserasian pandangan dan tindakan yang mengarah kepada kesatuan tindakan Cholik M., T \& Lutan, R, (1996/1997) Artinya, proses yang mem-persatukan di antara dua orang atau lebih (di antara kelompok). Proses asosiatif terdiri dari :

(1) Kerjasama yaitu bekerja secara bersama-sama karena mempunyai kepen-tingan yang sama. Kerjasama adalah suatu usaha bersama antara orang perorangan atau kelompok manusia untuk mencapai satu atau lebih tujuan bersama Pasau, Anwar (2012).).Kerjasama menembus semua aspek kehidupan sosial dan sangat penting sebagai salah satu upaya memelihara keadaan masyarakat yang stabil. Kerjasama terlahir karena orientasi orang terhadap kelompoknya (in group) dan terhadap kelompok lain (out-group). Kerja-sama erat kaitannya dengan aktivitas pendidikan jasmani khususnya kegiatan yang didominasi oleh olahraga dalam bentuk permainan. Dalam permainan, kerja sama memiliki peranan sangat penting. Untuk itu perlu diajarkan dan dibina sejak usia dini. Pada tahap yang lebih tinggi kerja sama ini sangat dibutuhkan. Kecenderungannya adalah bahwa kerjasama dalam kelompok akan dapat meningkatkan saling pengertian dan hubungan emo-sional dan perasaan yang lebih baik diantara sesama anggota tim atau kelompok. Kondisi seperti ini akan menimbulkan keterpaduan (integrasi) dan keterpautan (cohesiveness) yang sangat penting dalam upaya mempertinggi penampilan dan prestasi kelompok di cabang olahraga

(2) Akomodasi memiliki dua pengertian yaitu yang menunjukkan pada suatu keadaan dan menunjuk pada suatu proses. Pada suatu keadaan, akomodasi berarti adanya suatu keseimbangan (equilibrium) dalam interaksi antara orang perorangan atau kelompokkelompok manusia dalam kaitannya dengan norma dan nilai-nilai sosial yang berlaku di masyarakat. Sebagai suatu proses, akomodasi menunjukkan pada usaha-usaha manusia untuk meredakan pertentangan sebagai usaha untuk mencapai kestabilan, akomodasi adalah suatu proses mengem-bangkan persetujuan kerja di antara individu atau kelompok yang sedang berada dalam keadaan konflik. Akomodasi merupakan cara menyelesaikan masalah tanpa menghancurkan pihak lawan Suherman, Adang. (2000). Tujuan dilakukannya akomodasi tergantung pada situasi yang dihadapinya sehingga memiliki tujuan yang berbeda-beda.

(3) Asimilasi merupakan proses sosial dalam taraf lanjut yang ditandai dengan adanya usaha-usaha mengurangi perbedaan-perbedaan yang terdapat dian-tara orang perorangan atau kelompok-kelompok manusia dan juga usaha-usaha untuk mempertinggi kesatuan tindak, sikap serta proses mental dengan memperhatikan kepentingan dan tujuan bersama Suherman, Adang. (2000). Ketika dua kelompok mengadakan asimilasi maka karakter atau batas-batas diantara keduanya akan hilang dan keduanya melebur menjadi satu kelompok. Proses asimilasi ditandai dengan adanya pengembangan sikap yang sama, walaupun terkadang bersifat emosional, bertujuan untuk mencapai kesatuan, atau paling tidak mencapai kesatuan dalam organisasi, pikiran, dan tindakan. 
(4) Proses asimilasi timbul bila ada (1) kelompok-kelompok manusia yang berbeda kebudayaannya; (2) orangorang sebagai anggota kelompok tadi saling bergaul secara langsung dan intensif untuk waktu yang lama, sehing-ga (3) kebudayaan-kebudayaan dari kelompok tersebut masing-masing berubah dan saling menyesuaikan diri. Asimilasi terkait erat dengan pengembangan sikap dan cita-cita yang sama. Ketiga aspek tersebut sesungguhnya tercermin dalam kegiatan pembelajaran penjas yang bersifat aktif, meng-hargai perbedaan, dan interaksi sosial yang mendalam.

(5) Pada peritiwa pembelajaran pendidikan jasmani, melalui aktivitas jasmani diupayakan agar seluruh siswa dapat menerima keanekaragaman manusia beserta kebudayaannya, khususnya melalui keterlibatan sebagai pemain dalam sebuah tim olahraga. Misalnya ketika guru penjas menginstruksikan seluruh siswa untuk membentuk kelompok dalam sebuah pertandingan bola voli. Guru menentukan secara langsung keberadaan siswa dalam kelompok. Secara otomatis siswa harus mau bergabung dengan rekan yang bukan teman dekatnya, berbeda suku, agama, dan kebiasaannya. Tetapi pada saat itu pula dituntut kekompakan, sikap toleransi untuk dapat melakukan aktivitas sesuai instruksi guru. Dari contoh itu dapat terlihat bahwa asimilasi terjadi melalui aktivitas olahraga, sebab pada intinya asimilasi itu berintikan proses penerimaan orang lain dan kebudayaannya disertai sikap toleransi. Contoh nyata sesungguhnya adalah bagaimana masyarakat kita menerima beberapa cabang olahraga (karate, tinju, sepakbola) yang berasal dari negara lain bahkan perkembangannya mengalahkan olahraga asli yang lahir di Indonesia.

\section{Pendekatan Bermain}

$\begin{array}{rrrr}\text { Sidik, } & \text { Zafar } & \text { didik. } & \text { (2010). } \\ \text { pendidikan } & \text { jasmani } & \text { dan } & \text { olahraga }\end{array}$ berhubungan erat dengan unsur-unsur sosiologi manusia dan aktivitasnya, lembaga kemasyarakatan dan cara-cara bagaimana susunan di masyarakat dapat dibangun dengan mempergunakan keahlian, penelitian dan kepemimpinan yang diperlukan. Kebutuhan sosiologi manusia menjadi salah satu dasar sosiologi pendidikan jasmani. Kebutuhan sosiologi berkenaan dengan pola bagaimana seseorang dapat menyesuaikan diri dalam masyarakat. Kebutuhan itu antara lain adalah kerja sama, berbagi dengan orang, cinta, menghargai pendapat orang lain, suka berteman, dan keinginan mempengaruhi orang lain.

Kebutuhan manusia dapat direalisasikan melalui bekerja, berolahraga, dan berekreasi. Bila kebutuhan sosiologis itu tidak dipenuhi dan dikembangkan dengan baik, kemungkinan manusia dapat berperilaku anti sosial dan memiliki pola penyesuaian diri yang tidak baik. Karena itu pendidikan jasmani melalui program dan aktivitasnya berupaya dengan merencanakan cara-cara untuk memenuhi kebutuhan tersebut.Guru pendidikan jasmani kesehatan dan olahraga mempunyai posisi yang baik untuk memberikan kesempatan kepada siswa untuk berpartisipasi dalam aktivitas yang memberikan kepuasan bagi proses pemenuhan kebutuhan dasar sosiologisnya. Dalam proses pembelajaran penjas, siswa memenuhi kebutuhan sosiologisnya dengan menjadi anggota kelompok, misalnya diberi kesempatan bermain dalam sebuah tim olahraga. Siswa akan memperoleh pengakuan, persahabatan, persetujuan, dan penghargaan dari rekan satu timnya. Guru pendidikan jasmani harus memahami dengan sungguh-sungguh bahwa aktivitas 
jasmani seperti olahraga, terutama yang bersifat permainan, bukan hanya bertujuan agar siswa memiliki efisiensi dan koordinasi gerak, tetapi juga agar aspek sosial siswa berkembang dengan baik. Seperti dikemukakan Rosdiana, Dini. (2013).) bahwa aktivitas permainan bernilai mempersiapkan siswa bagi kehidupan sosial di masa mendatang., hubungan permainan dengan latihan anak di masyarakat adalah sebagai berikut:

(1) Permainan berhubungan dengan latihan kepatuhan dan disiplin.

(2) Permainan berkaitan dengan tugastugas rutin dan latihan tanggung jawab.

(3) Permainan biasanya berhubungan dengan latihan pencapaian tujuan atau sasaran dan menguasai lingkungan tempat ia berada.

Pendekatan bermain sering disebut juga metode bermain. Anggapan dasar-nya berlandaskan pada sifat manusia yang hakiki yaitu suka bermain. Sifat ini merupakan suatu segi dari manusia sebagai makhluk sosial, karena keterlibatan dalam permainan menuntut kesediaan mematuhi dan menjalankan peraturan dan sangsi yang pada hakikatnya berasal dari budaya masyarakat. Beberapa ahli mengatakan bahwa bermain adalah belajar menyesuaikan diri dengan keadaan. Pendapat Smith yang dikutip oleh Paturusi, Achmad.( 2012 )mengemukakan bahwa bermain adalah dorongan langsung dari dalam diri setiap individu, yang bagi anak-anak merupakan pekerjaan, sedang bagi orang dewasa lebih dirasakan sebagai kegemaran. Bermain adalah aktivitas yang dilakukan dengan rasa senang. Untuk mampu bermain dengan baik maka diperlukan memi-liki kesadaran untuk berlatih, mengetahui kemampuan teman, patuh pada pera-turan, dan mengetahui kemampuan dirinya sendiri.

Pendapat Ikhsan dan Hasmiyati. (2011). menyebutkan bahwa anak yang semula asosial melalui kegiatan bermain dengan rekan sebayanya, sedikit demi sedikit akan berkembang karena disosialisasikan. Perkembangan itu sebagai proses sosialisasi dalam bentuk imitasi (meniru) yang berlangsung dengan adaptasi dan seleksi. Hanya saja proses sosialisasi anak tidak selamanya berjalan dengan baik. Salah satu faktor penye-babnya adalah dorongan yang diberikan oleh orang yang lebih dewasa terkait dengan hasil akhir dari suatu kegiatan bermain. Ketika anak selalu dituntut untuk menjadi pemenang dalam suatu permainan dan tidak ada pilihan lain, maka anak akan dibiasakan menggunakan segala cara untuk menjadi yang terunggul. Perilaku seperti itu biasanya akan terbawa oleh anak untuk melanggar aturan, norma, dan etika yang berlaku di masyarakat, sehingga kegiatan bermain harus dicipta-kan sedemikian rupa dengan mengurangi dampak negatif yang mungkin terjadi dan yang dapat memberikan pengaruh jelek terhadap perkembangan sosial anak. Menurut Aip Syarifudin (1992)), pendekatan bermain banyak dilakukan karena di masyarakat telah biasa melakukannya. Hal itu disebut sosialisasi yang berlaku secara informal dalam bentuk permainan. Secara garis besar langkahlangkah yang dilakukan dalam menerapkan pendekatan bermain adalah sebagai berikut:

(1) Menetapkan sasaran yang akan dicapai.

(2) Menentukan jenis permainan sebagai aktivitas bermain siswa.

(3) Menjelaskan cara-cara dan aturan bermain dan selalu menjauhkan siswa dari bentuk aktivitas persaingan yang melahirkan pemenang dan yang kalah.

Misalnya guru memberikan tugas untuk melakukan permainan lompat tali. Secara tegas cara dan aturannya diungkapkan dan pengelompokkan siswa dibuat sesuai dengan tingkat kemampuannya, sehingga tingkat kemampuan melompat tidak terlalu senjang yang berdampak kepada terjadinya perasaan 
minder pada siswa yang paling rendah kemampuannya dan perasaan diri paling unggul pada siswa yang paling tinggi hasil lompatannya. Pendekatan bermain memiliki keuntungan dan kelemahan Paturusi, Achmad. (2012.) Keuntungan pendekatan bermain adalah sesuai dengan sifat dan kodrati manusia yang suka bermain, sehingga proses belajar mengajar menjadi lebih menarik. Termasuk juga sebagai salah satu proses pelestarian kebudayaan terutama pada bentuk-bentuk permainan tradisional masyarakat setempat yang dijadikan media pembelajaran pendidikan jasmani. Sedangkan kelemahannya adalah sering terjadi sasaran belajar tugas geraknya yang tidak jelas. Sebab tugas gerak yang diajarkan seringkali kurang jelas dan kurang tegas karena siswa memiliki kebebasan yang luas dalam melakukan perannya di suatu permainan.

Melalui bentuk-bentuk permainan yang sesuai dengan karakteristik siswa SD, penyajian bahan ajar penjas akan lebih menarik. Dampaknya adalah aktivitas belajar meningkat pula sehingga interaksi sosial diantara pelaku pembelajaran akan semakin lama dan mendalam. Peristiwa ini diharapkan pula dapat menumbuhkembangkan aspek-aspek sosial dalam

\section{Daftar Pustaka}

Aip Syarifudin (1992) Atletik. Jakarta Debdikbud .

Cholik M., T \& Lutan, R, (1997), Pendidikan jasmani dan kesehatan, Jakarta: Depdiknas Dirjen Dikti Bagian Proyek Pengembangan Penidikan Guru Sekolah Dasar

Husdarta H.J.S. (2011).Manajemen Pendidikan Jasmani. Bandung; Alfabeta bemtuk perilaku asosiatif yang berguna bagi perkembangan sosial siswa di masa mendatang.

\section{KESIMPULAN}

Aktivitas pembelajaran penjas yang didominasi bermain sesungguhnya akan mengarahkan siswa pada bagaimana berinteraksi sosial dengan sesamanya. Untuk mencapai hal tersebut guru penjas memiliki peran sangat penting dalam menciptakan lingkungan belajar siswa yang sesuai dengan minat dan kebutuhan (karakteristik siswa) sehingga harapan berkembanganya perilaku asosiatif siswa bisa menjadi kenyataan.Bermain dalam aktivitas penjas diyakini mampu menumbuhkembangkan seluruh potensi anak didik termasuk di dalamnya kemampuan. Dengan bermain bersama anak lain, anak-anak belajar bagaimana menetapkan hubungan sosial, dan bagaimana menemukan serta menyelesaikan masalah sehingga hubungan sosial menjadi lebih meningkat seperti halnya pada proses akomodasi dan asimilasi. Kemampuan sosial seperti itu merupakan salah satu indikator dari proses sosial yang asosiatif.

Ikhsan, Andidan Hasmiyati. (2011). Manajemen Pendidikan Jasmani dan Olahraga. Makasar: UNM

Pasau, Anwar (2012). Pertumbuhan dan Perkembangan Fisik Pendidikan Jasmani,Olahraga, dan Kesehatan. Makasar: UNM

Paturusi, Achmad. (2012.) Manajemen Pendidikan Jasmani dan Olahraga. Jakarta: Rineka Cipta. 
Rosdiana, Dini. (2013).Perencanaan Pembelajaran Dalam Pendidikan Jasmani dan Kesehatan.Bandung: Alfabeta

Sidik, Zafar didik. (2010). Mengajar dan Melatih Atletik.Bandung:

Remaja Rosdakarya
Suherman, Adang. (2000). Dasar-dasar Pendidkan Jasmani dan Kesehatan. Depertemne Pendidikan dan Kebudayaan

Kadir Abdul Ateng (1992) Azas dan Landasan Pendidikan Jasmani. Jakarta :Depdikbud.Ditjen Dikti 